\title{
Berehalako mezularitzan erabilitako hizkuntza: ezaugarriak eta erabiltzaileen pertzepzioak
}

Garbiñe Bereziartua Etxeberria

Hizkuntzaren eta Literaturaren Didaktika Saila

Bilboko Irakasleen Unibertsitate Eskola

Euskal Herriko Unibertsitatea UPV/EHU

DOI: $10.1387 / \operatorname{tantak.17864}$

GAKO-HITZAK: ordenagailu bidezko komunikazioa, testismoak, berehalako mezularitza, euskara.

\section{SARRERA}

Azken urteetan teknologiak izan duen garapenak esparru askotan izan du eragina, horien artean pertsonarteko komunikazioan. Ordenagailuko konexioaren bitartez trukatzen diren mezuei «Ordenagailu Bidezko Komunikazioa» (Computer Mediated Communication, CMC) deitu ohi zaio gai hau aztertzen duen komunitate zientifikoan. Honela definitu izan da: «communication that takes place between human beings via the instrumentality of computers» (Herring, 1996:1).

Azken 20 urteetan asko garatu da Ordenagailu Bidezko Komunikazioa (ikus, esaterako, Herring 1996; Thurlow, Lengel eta Tomic 2004; Herring, Stein eta Virtanen 2013). International Telecommunication Union-en arabera (2015), 2015. urtearen amaieran 3,2 bilioi pertsonak erabili dute Internet eta 7 bilioi baino gehiago izango dira telefono mugikorretako harpidetzak. Gainera, Baker eta White-ren arabera (2010:1591), «[adolescents] represent the largest and fastest growing demographic sector using the Internet». Eta, horrez gain, 13 eta 19 urte arteko gazteen adin-tartea da internet gehien erabiltzen duen eta elkarren artean ordenagailu eta telefono mugikorren bidez gehien komunikatzen den adin-tartea (Herring eta Kapidzic 2015; Lenhart et al. 2010).

Tagliamonte eta Denis-ek (2008) diotenez, badira bi parametro, Ordenagailu Bidezko Komunikazioan (OBK) erabilitako mezuak sailkatzeko lagungarri izan daitezkeenak: mezuaren hartzaile kopurua eta mezuaren 
denboralizazioa (ikus Crystal 2001:151). Hartzaile kopuruari dagokionez, mezu bat diadikoa izango da buruz buruko elkarrizketa bat denean, eta parte-hartzaile anitzekoa (multiparticipant) izango da elkarrizketa talde baten barruan gertatzen denean. Mezuaren denboralizazioari dagokionez, sinkronikoa izango da erantzuna berehalakoa edo ia berehalakoa izatea espero denean eta asinkronikoa elkarrizketa denbora tarte zabal batean gauzatzen denean. Herring-ek (2010) dio mezu sinkronikoetan aukera gutxiago dagoela mezuak editatzeko eta aurrez aurrekoen antz gehiago daukatela elkarrizketa horiek.

Ordenagailu Bidezko Komunikazioaren beste ezaugarri bat da dinamikoa izatea. Teknologia garatzen doan heinean eta hardware nahiz software garatuagoak sortzen ari diren heinean Ordenagailu Bidezko Komunikazioa ere aldaketa horietara egokitzen ari da etengabe. Esaterako, gailu mugikorretako berehalako mezularitzaren esparruan aldaketa handiak gertatu dira azken urteetan. Baron-ek (2003:22) dioen moduan, «[Computer Mediated Communication] tends to be at once a diffuse and a moving target».

Ordenagailu bidez komunikatzeko erabiltzen den hizkuntzaren inguruan ikerketa asko ari dira egiten azken urteetan. Batetik, hizkuntza horrek dauzkan ezaugarriak aztertu dira (Amonarriz 2008, Plester, Wood eta Joshi 2009, Varnhagen et al. 2010, De Jonge eta Kemp 2012, Grace et al. 2014, Drouin eta Driver 2014); bestetik, hizkuntza-aldaera hori erabiltzearen atzean dauden arrazoiak zeintzuk izan litezkeen ikertu da (Plester, Wood eta Joshi 2009, De Jonge eta Kemp 2012, Grace et al. 2014); eta, horiekin batera, hizkuntza informal horrek eragin kaltegarririk sortzen ote duen ikusteko ikerketak egiten ari dira (Thurlow 2006, Plester, Wood eta Joshi 2009, Drouin eta Driver 2014). Esku artean dugun ikerketan, aipatu berri ditugun lehenengo bi esparruetan jarri dugu begia.

Nerabeen artean Ordenagailu Bidezko Komunikazioan erabiltzen den hizkuntzaren ezaugarriei buruz egindako ikerketa gehienak ingelesari begira egin izan dira. Esku artean dugun artikuluan euskarari begiratuko diogu eta ikusiko dugu zeintzuk diren bataren eta bestearen arteko antzekotasun nahiz desberdintasunak. Horrekin batera, hizkuntza-aldaera hori erabiltzearen atzean egon litezkeen arrazoiak ezagutzeko erabiltzaileek daukaten pertzepzioa ezagutzea da gure ikerketaren beste helburu bat.

\section{ORDENAGAILU BIDEZKO KOMUNIKAZIOKO HIZKUNTZAREN EZAUGARRIAK}

Teknologia garatzearekin batera ugaritu egin dira hizkuntza erabiltzeko esparruak eta bideak. Komunikatzeko bide berriak sortu dira, eta komunikatzearen oinarrian hizkuntza egonik, hizkuntza erabiltzeko modu berriak 
jaio dira. Horrek guztiak bereziki eragin dio hizkuntzaren idatzizko aldaerari.

Idatzizko hizkuntzaren aldaera berri bat sortu dela esan duten ikertzaileak bat baino gehiago izan dira; esaterako: Androutsopouloulos-ek (2000) «Non-Standard Spelling» izendapena erabili zuen «for spellings that diverge from standard (codified) orthography and/or do not occur in formal writing», Crystal-ek (2001) «Netspeak» deitu zion, Varnhagen eta bere kideek (2010) «New Language» izendatu zuten, eta «cyberspeak» edo «internet language» izenak ere erabili izan dira (Herring, Stein eta Virtanen 2013).

Ordenagailu Bidezko Komunikazioan (OBK) hizkuntzaren aldaera idatzia erabiltzen da, baina ahozko hizkuntza-aldaeraren ezaugarri asko dauzka. Desberdintasun handiak daude tradiziozko hizkuntza idatziaren eta OBKn erabiltzen den idatzizko hizkuntzaren artean. Ahozko hizkuntzatik gertu dagoen aldaera moduan ikusten du jendeak, Herring-ek (2010) azaltzen duenez erabiltzaileek OBKn erabiltzen den hizkuntzan aritzerakoan «hitz egin», «esan» eta «entzun» aditzak erabiltzen baitituzte.

Hala ere, ahozko hizkuntzaren eta OBKn erabiltzen den hizkuntzaren artean badira desberdintasunak. Crystal-en (2001) ustez desberdintasun nabarmenena da ezin dela hartzailearengandik aldibereko feedback-ik jaso. Eta, horrez gain, ez dagoela prosodiarik eta parahizkuntzarik. Alegia, OBKn erabiltzen den idatzizko hizkuntzan ez dagoela intonaziorik, aurpegiko espresiorik, keinurik eta gorputz-hizkuntzarik jarrerak eta iritziak adierazteko. Crystal-ek (2001:47) ondorioztatzen du OBKn erabiltzen den idatzizko hizkuntzak «has far more properties linking it to writing than to speech».

Esan dezakegu OBKn erabiltzen den hizkuntza, idatzizkoaren eta ahozkoaren artean dagoela, nonbait, eta ez batenak eta ez bestearenak ez diren zenbait ezaugarriren jabe ere badela. Baron-ek (2004) AEBetako unibertsitateko ikasleek izandako ordenagailu bidezko 23 elkarrizketaz osatutako corpusa (guztira 11.718 hitz) aztertu zuen, eta bere azterketan bai hizkuntza idatziaren eta bai ahozkoaren ezaugarriak ikusi zituen. Alde batetik, aurrez aurreko elkarrizketetan gertatu ohi den moduan, parte-hartzaileek hainbat txanda behar izan zituzten elkarrizketak amaitzeko; baina, beste aldetik, idazten zihoazen heinean beren akats tipografikoak zuzentzen joan ziren, idatzizko testuak editatzerakoan egin ohi den moduan.

Ordenagailu Bidezko Komunikazioan erabiltzen den hizkuntzaren ezaugarriak ikertu izan dira eta ezaugarri horiei buruz hitz egiteko erabiltzen den termino orokorra textisms (aurrerantzean testismoak) da (ikus, esaterako, De Jonge eta Kemp 2012; Grace et al. 2014). Ezaugarri horietako batzuk zuzenki lotuta daude OBKren ezaugari teknikoekin eta aurrez aurreko interakzioarekin konparatuta sortzen diren mugekin. Esaterako, batetik, mezuek motzak izan behar dute gailuetako pantailaren tamainaren, 
teklatuaren eta karaktere kopuruari dagokionez egon daitezkeen mugen ondorioz. Eta, bestetik, emozioak adierazteko baliabideak sortu behar dira. Testismoak erabiltzearen arrazoia neurri batean bada nolabait hutsune horiek betetzea, baina oraindik haratago doa. Geroago ikusiko dugunez, hori izan liteke bide bat taldekide-sentipena garatzeko, bereziki nerabeen artean (Baron 2003; Kemp, Wood eta Waldron 2014).

Ingelesez egiten den OBKn erabiltzen den hizkuntzaren ezaugarriak sailkatzeko hainbat taxonomia erabili izan dira (esaterako: Varnhagen et al. 2010; De Jonge eta Kemp 2012; Grace et al. 2014). Taxonomia horiek alderatuta ikusten da batzuek testismoen formari erreparatzen diotela, eta beste batzuek funtzioari. Grace eta bere kideek (2014) formari begiratzen diote eta hizkuntza idatziaren aldaera estandarra eta testismoen artean dauden desberdintasunen kategorizazio bat egiten dute. Testuak egokitzeko erabili diren estrategien arabera 15 kategoria desberdintzen dituzte. Kemp, Wood eta Waldron-ek (2014) ere formari begiratzen diote eta lau kategoria nagusi bereizten dituzte: puntuaziorik eza, kapitalizaziorik eza, hitzen mailako edo gramatikaren mailako akatsak eta ezohiko puntuazioa.

Varnhagen eta bere kideek (2010) formarekin eta funtzioekin lotutako irizpideen konbinazio bat egiten dute eta hiru kategoria nagusi bereizten dituzte: laburdurak, operadore pragmatikoak eta akatsak. Laburdurek eta akatsek formari begiratzen diote eta operadore pragmatikoek erabilitako operadorearen funtzioa hartzen dute kontuan.

Ingelesa ez den beste hizkuntza batzuetan esparru informalean erabiltzen den hizkuntzaren ezaugarriak sailkatzeko taxonomiak ere egin izan dira. Esaterako, Androtsopoulos-ek (2000) Alemaniako azpi-kultura mugimenduetako fanzineetan erabiltzen zen ortografia aztertu zuen eta hor erabiltzen zen hizkuntzak zituen ezaugarrien tipologia bat proposatu zuen. Sei multzotan sailkatzen ditu ezaugarri horiek: (1) Phonetic spellings (esaterako, «was» idatzi beharrean «wuz» idaztea); (2) Colloquial spellings; (3) Regiolectal spellings; (4) Prosodic spellings (adibidez, bokalak luzatzea); (5) Interlingual spellings; eta (6) Homophone spellings (adibidez, «you» idatzi beharrean «U» idaztea). Androutsopoulos-ek sortutako taxonomia hedabideetako idazkera ez arautua aztertzeko egin zen arren, oso baliagarria da OBKn erabiltzen den berehalako mezularitzako hizkuntzaren ezaugarriak aztertzeko.

Horrez gain, euskaraz egiten den OBKn erabiltzen den hizkuntzaren ezaugarriak sailkatzeko 1 taulan ikus dezakegun taxonomia proposatzen du Amonarriz-ek (2008): 
1. taula

Euskal Herriko gazteen idatzizko hizkeraren ezaugarriak

(Amonarriz, 2008)

\begin{tabular}{l|l|l}
\hline \multicolumn{2}{c|}{ Ezaugarriak } & \multicolumn{1}{c}{ Adibideak } \\
\hline \multirow{4}{*}{ Laburdurak } & Hizkiak soberan (batez ere bokalak) & Nn ao? Aln zz? \\
\cline { 2 - 3 } & Akronimoak & $\begin{array}{l}\text { AMZ (=asko maite zaitut) } \\
\text { ZG (=Zer gise?) }\end{array}$ \\
\cline { 2 - 3 } & H-a desagertzea & Ire, Or do \\
\cline { 2 - 3 } & Zenbakiak silaben ordez & D21, 3nn, nr 4na d. \\
\hline Ikonoak & & $;-($ \}\{ \\
\hline \multirow{4}{*}{ Indargarriak } & Onomatopeiak & «W» (wazen) \\
\cline { 2 - 3 } & Letra larriak & Jajajaj, jurjur, ajaj, zzzz \\
\cline { 2 - 3 } & Puntuazio markak errepikatuta (harridura, galdera...) & Zer???? \\
\cline { 2 - 3 } & Hizki errepikatuak & Bbaizeaaaa, aioooooo \\
\hline Hizki larririk eta puntuazio markarik ez & ZEEE? \\
\hline \multirow{2}{*}{$\begin{array}{l}\text { Akats ortografikoak } \\
\text { Ahozko erabileratik hurbil }\end{array}$} & \\
\hline
\end{tabular}

Esku artean dugun artikuluan Varnhagen eta bere kideek (2010) proposatutako hiru kategoria nagusietan oinarrituko gara baina kontuan hartuko ditugu Grace eta bere kideek (2014), Kemp, Wood eta Waldron-ek (2014) nahiz Amonarriz-ek (2008) proposatutako kategoria batzuk ere. Beraz, hauek dira guk erabiliko ditugun kategoriak: 1) laburdurak; 2) alderdi pragmatikoak eta baliabide emozionalak; eta 3) akatsak.

1. «Laburdurak» kategoriaren barruan honako ezaugarriak bildu ditugu:

- Elkartutako hitzak: berez hitz bat baino gehiago diren arren, hitz bakar bat balira bezala ahoskatzen direnak. Adibidez: egin behar-en ordez inber.

- Laburtutako hitzak (Shortenings): hitzak laburtu egiten dira fonemak edo morfemak kenduta. Adibidez: bestela-ren ordez bstla. 
- Akronimoak: hitz bat baino gehiagoko serie batean hitz horietako bakoitzaren hasierako hizkiak hartuta osatzen diren hitzak. Adibidez: zer moduz zaude-ren ordez zmz.

- Hizki-aldaketa homofonoak: hitz bat edo hitz baten zati bat modu berberean ahoskatzen den beste hizki batzuez ordezten denean. Adibidez: guapa-ren ordez wapa.

Grace eta bere kideek (2014) hainbat kategoria desberdintzen dituzte guk laburduren kategoriaren barruan sartu ditugun ezaugarrien artean, esaterako: shortenings (Tuesday-ren ordez Tue), contractions (please-ren ordez pls), ommitted apostrophes (won't-en ordez wont) eta G-clippings (having-en ordez havin). Grace eta bere kideek (2014) identifikatutako zenbait kategoriak balio dute ingeles hizkuntzarako (apostrofeak ez erabiltzea edo G-clipping) baina ez dute balio hizkuntza guztientzako, ingeles hizkuntzak dauzkan egitura horiek ez daudelako beste hizkuntzetan.

Varnhagen eta beraren kideek (2010) «insider word» izena ematen diete slang hitzei eta laburduren kategoriaren barnean sartzen dute, baina guk ezaugarri hori ez dugu kontuan hartu, ez delako laburdura.

Laburdurek funtzio berezia betetzen dute Ordenagailu Bidezko Komunikaziorako erabiltzen den hizkuntzaren barruan, espazioa, denbora eta esfortzua aurrezten laguntzen baitute. Baron-ek (2003) esaten duenez, laburdurak ez dira orain sortuak «... abbreviations (and acronyms) have long been part of the written language tradition, appearing both in handwritten manuscripts and print». Eta gaur egun ere asko erabiltzen dira OBKn.

2. «Operadore pragmatiko»en artean honako ezaugarri hauek bildu ditugu:

- Hizkiak luzatzea: hitz bateko hizkiak errepikatu (luzatu) egiten dira ahozko hizkuntzaren intonazioa eman nahian. Adibidez: kaixo-ren ordez kaixoooo.

- Hizki larriak: oihu egitea irudikatzeko hizki larriz idatzi ohi dira hitzak. Adibidez: ez etsi-ren ordez EZ ETSI.

- Emozio-hitzak: onomatopeiak-edo erabiltzen dira emoziozko adierazpenak egiteko. Adibidez: jajajajaj (barrearen hotsa irudikatzeko).

- Emozio-puntuazioa: puntuazio ikurrak errepikatu egiten dira enfasia emateko (adib., !!!!!!!).

Taxonomia batetik bestera aldatu egiten da baliabide pragmatiko eta emozionalak kategorizatzeko edo izendatzeko modua. Esaterako, Varnhagen eta beraren kideek (2010) emotion punctuation adiera erabiltzen dute Grace eta beraren kideek (2014) extra punctuation edo Kemp, Wood eta Waldron-ek (2014) unconventional punctuation deitzen dutena izendatzeko. 
Kategoria honen barruan biltzen dira OBKn erabiltzen den hizkuntza ahozko hizkuntzara gerturatzeko erabiltzen diren estrategiak eta, orobat, idatzizko hizkuntza horrek dauzkan muga komunikatiboak gainditzeko erabiltzen diren estrategiak (helburu komunikatiboak, jarrerak eta emozioak). Esaterako, hitz jakin batean bokalak luzatzeak ahozko hizkuntzan intonazioarekin edo aurpegiko espresioarekin adierazten den enfasia islatu nahi du. Irribarrea adierazten duen emotikoi batek mezu bat leundu lezake jarrera atsegin bat erakutsiz. Emotikoiak kategoria honetan sar litezke baina esku artean dugun ikerketan ez dira kontuan hartu.

3. «Akatsak» kategoriaren barruan honako ezaugarri hauek sartu ditugu:

- Tipografikoak: teklatuan idazterakoan teklaz nahasteagatik sortutako akatsak. Adibidez: ikusi-ren ordez iksui.

- Ortografikoak: ortografia arauak bete gabe idatzitakoak. Adibidez: aspaldi-ren ordez azpaldi.

Akatsei dagokienez, kontuan hartu behar dira hizkuntzen artean dauden desberdintasunak. Akats tipografikoen kasuan ez dago alderik hizkuntza batetik bestera, ordenagailuko teklatua erabiltzeko trebetasunarekin eta idatzitakoa editatu gabe bidaltzearekin lotuta baitaude. Baina akats ortografikoen kasuan gogoratu behar dugu euskara hizkuntza gardena dela, alegia, fonema-ortografia korrespondentzia daukan hizkuntza dela eta akats ortografikoak egiteko maiztasuna urriagoa izatea ekartzen duela horrek. Euskaraz egin daitezkeen akats ortografikoak bi dira: «h» hizkiaren erabilera okerra (dagokion tokian ez jartzea edo ez dagokion tokian jartzea) eta «s» eta «Z» hizkiak nahastea.

OBKko hizkuntzan erabiltzen diren testismoak deskribatzeaz gain, garrantzitsua da testismoen dentsitatea zenbatekoa den jakitea ere. Tagliamonte eta Denis-ek (2008) Kanadako 15 eta 20 urte arteko 71 pertsonaren datuak jaso zituzten eta ikusi zuten corpusaren \% 2,4a zirela testismoak. Baron-ek (2003) Amerikar Estatu Batuetako 23 unibertsitate-ikasleren elkarrizketak aztertu zituen eta ikusi zuen laburdurak corpusaren $\% 0,3$ osatzen zutela, eta akronimoek \% 0.8. De Jong eta Kemp-ek (2012) Australiako 53 unibertsitate-ikasleri eta bigarren mailako hezkuntzako 52 ikasleri eskatu zieten ingelesezko aldaera estandarrean idatzita zeuden mezu batzuk ordenagailu bidez idatzitako mezuak izan balira bezala idazteko eta ikusi zuten testismoak mezuetako hitzen arteko \% 13-\% 16 artean zeudela. Azken ikerketa hori egoera errealen gertatu ez zen arren, kontuan hartzekoa izan liteke hala ere. Drouin eta Driver-ek (2014) Amerikar Estatu Batuetako 183 unibertsitate- ikasleren SMS mezuak aztertu ondoren, 7.161 hitzeko corpus batean hitzen \% 24 testismoak zirela ikusi zuten.

OBKn erabiltzen den hizkuntzak bere mugak dituela onartzen da, neurri batean bitartekoaren beraren ezaugarri fisikoek eraginda (Herring, Stein 
eta Virtanen 2013). Ezaugarri fisiko horiek munduaren ezein alderditan bertsuak izango direnez, esan liteke OBKn erabiltzen den hizkuntzaren ezaugarriak ere antzekoak izango direla, neurri batean teknologiak xedatzen baititu. Baina gerta liteke testismoen erabilera ez izatea muga teknologikoen ondorioz sortu den zerbait bakarrik. Herring, Stein eta Virtanen-ek (2013:9) diotenez, «[the new technology] enables new kinds of participation, new kinds of fragmentation, and new ways of co-constructing meaning that transcend traditional notions of conversation, narrative, exposition and so forth».

OBKn erabiltzen den hizkuntzaren inguruko ikerketa gehienek ingelesari begiratu izan diote eta gutxi dira beste hizkuntza batzuk kontuan hartu izan dituztenak (ikus, esaterako, Danet eta Herring 2007; Amonarriz 2008; Androutsopoulos 2015; Dyers eta Davids 2015). Herring-ek (2010) eta Herring, Stein eta Virtanen-ek (2013) azpimarratzen dute beharrezkoa dela ingelesa ez beste hizkuntzetan ikerketak egitea, ingelesak OBKn erabiltzen denean dauzkan ezaugarriak eta beste hizkuntza batzuenak antzekoak zein neurritaraino diren ikusteko. Eta horixe da, hain zuzen ere, artikulu honetan azaltzen den ikerketak egin nahi duen gauzetako bat: neurri batean hutsune hori bete, euskara bezalako hizkuntza gutxitu bateko nerabeek OBKn erabiltzen duten hizkuntzaren ezaugarriak aztertuta.

\section{ORDENAGAILU BIDEZKO KOMUNIKAZIOAN ERABILTZEN DEN HIZKUNTZA-ALDAERA ERABILTZEKO ARRAZOIAK}

Ordenagailu bidezko komunikazioan erabiltzen den hizkuntzaren ezaugarri nabarmenetako bat testismoak erabiltzea dela ikusi dugu. Ikusi dugu testismoak erabiltzeko arrazoietako bat teknologiak ezartzen dituen mugak direla, baina horrez gain arrazoi gehiago eta erabilera horretan eragiten duten faktore gehiago ere badaudela erakutsi dute hainbat ikerketak. Esaterako, bereziki nerabeen artean taldekide-sentipena garatzeko erabili ohi direla ikusi da (Baron 2003, Kemp, Wood eta Waldron 2014). Amonarriz-ek (2008) transgresio-nahiarekin lotzen ditu testismoak, ulergarritasuna arau bakarra izanik hizkuntzaren aldaera estandarraren arauak ez direla errespetatzen eta ekonomia eta adierazkortasuna bilatzen direla esaten du. Eta Ling eta Ytri-k (2002) ere bat egiten dute azken ideia horrekin eta aurrekoekin nerabeen eta beren gurasoen arteko desberdintasunak markatzeko funtzioa bete eta talde bateko kidetza-sentimendua indartzen dutela esatean. Idazteko modu araututik irtetea modu kolektiboan egiten denean identitate soziala eta kulturalaren isla izan daiteke.

Testismoen erabileran eragiten duten faktoreak ere badaudela nabarmendu dute zenbait ikerketak. Esaterako, Drouin eta Drivek-ek (2014) diotenez zenbait testismo hizkuntzaren erabilera sortzailearen isla dira baina beste batzuk zuzentasunaren arauak errespetatuz idazteko ezinta- 
sunaren ondorio direla esaten dute. Grace eta beraren kideek (2014) aurreko bi alderdi horiek kontuan hartzen dituzte eta eransten dute testismoen erabileran eragiten duten faktoreen artean alfabetatze-gaitasuna (literacy skills) ere kontuan hartu behar dela. De Jonge eta Kemp (2012) ere bat datoz azken ideia horrekin eta erabiltzaileak daukan alfabetatzegaitasunaren arabera testismoak erabiltzeko arrazoiak desberdinak direla esaten dute:

... texters might vary their spelling for different reasons: poorer spellers because they cannot remember the exact version they used last time, and better spellers because they are having fun with language, or tailoring their textisms to suit the message recipient. Further, texters of any ability may vary the textism they use for a word according to the length of the message or the time available to write it. (De Jonge eta Kemp 2012:63)

Hala ere, testismoak erabiltzearen atzean dauden arrazoiak eta eragiten duten faktoreak aztertu diren ikerketetan ikertzaileen interpretazioak izan dira argitara eman direnak eta ez dira kontuan hartu erabiltzaileek gai horren inguruan dauzkaten iritziak eta pertzepzioak. Grace eta beraren kideek (2015) esaten dute komenigarria litzatekeela hori egitea eta «asking students to explain the motivation behind their use of such spellings and symbols would allow more definite conclusions to be drawn» (Grace et al. 2015:804). Eta horixe da, hain zuzen ere, esku artean dugun ikerketan egin duguna: ikerketan parte hartu duten nerabeek testismoak erabiltzearen gainean dauzkaten pertzepzioak zein diren jakitea.

\section{GURE IKERKETA ETA HELBURUAK}

Ordenagailu bidez komunikatzearen eta horretarako erabiltzen den hizkuntzaren inguruan geroz eta ikerketa gehiago egiten ari dira azken urteetan. Gure ikerketarekin bi edo hiru ekarpen egin nahi genizkioke gai horri.

Batetik, ordenagailu bidezko komunikazioan erabiltzen den hizkuntzaren ezaugarriei buruz egin diren ikerketa gehienak ingelesa oinarri hartuta egin dira. Gure ikerketan euskara hartu dugu oinarri. Ingelesetik oso desberdina den hizkuntza da eta, gainera, ingelesak eskolatik kanpo oso presentzia txikia daukan testuinguru batean gauzatu da. Ingelesaren eragina nahiko mugatua den testuinguruan kokatutako ikerketa egiteak ordenagailu bidezko komunikazioan erabiltzen den hizkuntzaren ezaugarrien unibertsaltasuna frogatzeko aukera eman du.

Bestetik, ikerketa hau egiteko parte-hartzaileek testuinguru naturalean izandako elkarrizketak aztertu dira (ikusi Tagliamonte eta Denis 2008; Varnhagen et al. 2010). Hala ere, Drouin eta Driver-ek (2014:251) diotenez, gai honen inguruan egin izan diren ikerketa gutxitan aztertu dira testuinguru naturalean sortutako datuak eta, kasu honetan bezala, hori horrela egiteak «give ecological validity to the findings». 
Eta, azkenik, testuinguru euskalduneko gazteek ordenagailu bidez erabiltzen duten hizkuntzaren ezaugarriak aztertu eta gazte horiek testismoak erabiltzearen inguruan dauzkaten pertzepzioak aztertu ditugu. Izan ere, Grace eta beraren kideek (2015) esaten dutenaren harira testismoak erabiltzearen atzean dagoen motibazioa zein den jakiteko garrantzitsua da erabiltzaileen pertzepzioak ezagutzea eta hori da gure ikerketak egiten duena.

Helburu horiek maila zehatzago batera eramanda, ikerketa-galdera hauei erantzun nahi izan diegu:

1. Euskaraz komunikatzen diren gazteek ordenagailu bidez erabiltzen duten hizkuntzaren ezaugarriek bat egiten al dute ingelesez erabiltzen duten hizkuntzaren ezaugarriekin? Alegia, ordenagailu bidez komunikatzeko erabiltzen den hizkuntzaren ezaugarriak unibertsalak direla esan al dezakegu?

2. Testuinguru euskalduneko gazteek zer pertzepzio daukate berek ordenagailu bidez erabiltzen duten hizkuntzaren inguruan?

Ikerketa-galdera honek parte-hartzaileen ikuspuntua hartzen du kontuan eta testuinguru euskalduneko gazte horiek testismoak erabiltzeko dauzkaten arrazoietan jarri nahi du begia.

\section{METODOLOGIA}

\section{Parte-hartzaileak}

Ikerketa Azpeitian egin da eta bertan dauden hiru ikastetxeetako DBH-3 eta DBH-4 mailako 299 ikaslek hartu dute parte. Azpeitian ikasten duten 14-16 urte bitarteko ia gazte guztiak (hiru ikastetxe horietako batean curriculumaren dibertsifikazioa egiten den gelako ikasleak, 16 ikasle, ez beste guztiak) eta batez besteko adina 14,79 izan da. Parte-hartzaileen sexu-banaketari dagokionez, \% 47,8 gizonezkoak eta \% 52,2 emakumezkoak izan dira.

Hiru ikastetxeetan D ereduan irakasten dute; beraz, euskara da instrukzio-hizkuntza eta gaztelania eta ingelesa ikasgai moduan jasotzen dituzte.

Parte-hartzaileen errepertorio linguistikoa aberatsa da. Euskara batuan eta herriko euskalkian hitz egiten dute, gaztelaniaz hitz egiteko ez daukate arazorik eta ingelesa ikasten ari dira. Parte-hartzaileen \% 98rentzat euskara da lehen hizkuntza. Euskara da egunerokotasunean komunikatzeko erabiltzen duten hizkuntza (barne-pentsamenduak \% 88; anai-arreben artean \% 84,4; ikastetxean \% 95,6; lagunekin \% 94; sare sozial birtualetan \% 91,6). Parte-hartzaileek euskara batua erabiltzen dute ikastetxeko testuinguruan, instrukzio-hizkuntza moduan, baina pertsonarteko komunikazioan herriko euskalkia erabiltzen dute. Esaterako, parte-hartzaileen \% 91k 
esan du euskalkia erabiltzen duela sare sozial birtualetan komunikatzeko eta ikerketa honetarako jasotako corpusaren \% 100 euskalkian idatzita dago.

\section{Datu-bilketarako tresnak}

Ikerketako datuak biltzeko hiru tresna erabili ditugu: oinarrizko informazioa jasotzeko galdetegia, gazteek sare sozial birtualetan izandako elkarrizketak eta gazte horiekin egindako talde-eztabaidak.

Galdetegia erabili dugu parte-hartzaileen hizkuntzaren gaineko ezagutza eta testuinguru desberdinetan erabiltzen duten hizkuntzari buruzko informazioa jasotzeko (familiarekin, lagunekin, ikastetxean eta teknologia tarteko dela). Galdetegiaren bidez jasotako datuak SPSS programaren bitartez aztertu ditugu.

Sare sozial birtualetako elkarrizketak lortzeko parte-hartzaileei eskatu zitzaien berek Tuenti sare sozialean lagunekin izandako elkarrizketak modu boluntarioan emateko. Guztira 54 elkarrizketa diadiko jaso ditugu. Elkarrizketa horietan jasotako corpusa 7411 hitzez osatuta dago eta elkarrizketa bakoitzeko hitzen kopurua 23 eta 433 hitzen artekoa da, batez besteko kopurua 137,2 (DT 94,4) izanik. Datu horiek aztertzeko SPSS programa erabili dugu.

Sei talde-eztabaida egin ditugu, ikastetxe bakoitzeko eta maila bakoitzeko bat. Talde bakoitzean 4/8 ikasle inguruk parte hartu dute. Guztira, 34 lagunek hartu dute parte: 19 neska eta 15 mutil. Eztabaida hauetan parte hartu duten pertsonak ikastalde bakoitzerako ikasleek ordezkari moduan aukeratuta zeuzkaten kideak izan dira. Elkarrizketen iraupena 52 eta 85 minutu artekoa izan da, batez beste 68 minutu. Talde eztabaidetan jasotako informazioa ATLAS.ti programaren bidez prozesatu dugu.

\section{Prozedura}

Gure ikerketan parte hartzea nahi genuen ikastetxeekin harremanetan jarri eta ikerketaren berri eman ostean, guztiak prest agertu ziren parte hartzeko. Datuak noiz eta nola biltzeko pausoak zehaztu eta adostu ondoren horri ekin genion.

Ikasleek esparru informalean izandako elkarrizketetako hizkuntza aztertzean ikusitako testismoak aurrez azaldutako hiru kategoriatan sailkatu ditugu: laburdurak, baliabide pragmatiko eta emozionalak, eta akatsak. Lehen esan bezala, ikerketa honetan erabilitako taxonomia egiteko bereziki Varnhagen eta beraren kideek (2010) proposatutako taxonomian oinarritu gara, baina beste zenbait taxonomia ere kontuan hartu ditugu (Amonarriz 2008; Grace et al. 2014; Kemp et al. 2014). 
Talde-eztabaidak ikastetxe guztietako ikasleekin egin genituen, ikastetxe eta maila bat aldiko. Eztabaidak ikastetxetik kanpo egin genituen eta horretarako baimena eman zuten parte-hartzaileen gurasoek. Talde-eztabaidetan jasotako datuak transkribatu eta edukiaren arabera aztertu genituen, ikasleek testismoak erabiltzeko zeuzkaten arrazoiei buruz esandakoak bereziki kontuan hartuz.

\section{EMAITZAK}

Lehenengo ikerketa-galderaren helburua, euskaraz komunikatzen diren gazteek ordenagailu bidez erabiltzen duten hizkuntzaren ezaugarriek ingelesez erabiltzen denarekin dauzkaten antzekotasunak eta desberdintasunak aztertzea da. Galdera horri erantzuteko jasotako 54 elkarrizketa diadikoetan identifikatutako ezaugarri linguistikoak konparatu ditugu Varnhagen eta beraren kideek (2010), Grace eta beraren kideek (2014) eta Kemp eta beraren kideek (2014) deskribatutakoekin. Ondoren ezaugarri horien maiztasunari erreparatu diogu. Guk jasotako euskarako corpusean identifikatutako ezaugarriak eta ingelesezko parekideak 2. taulan ikus daiteke.

\section{2. taula}

\section{Ordenagailu bidezko komunikazioan erabiltzen den hizkuntzaren ezaugarriak ingelesez eta euskaraz}

\begin{tabular}{l|l|l|l}
\hline \multicolumn{2}{c|}{ Ezaugarriak } & \multicolumn{1}{c|}{ Ingelesez } & \multicolumn{1}{c}{ Euskaraz } \\
\hline \multirow{4}{*}{\begin{tabular}{l} 
1. Laburdurak \\
\cline { 2 - 4 }
\end{tabular}} & Hitzen konbinazioa & wanna (want to) & eztakit (ez dakit) \\
\cline { 2 - 4 } & Akronimoak & tmrw (tomorrow) & $\begin{array}{l}\text { nd (ondo) } \\
\text { t eta })\end{array}$ \\
\cline { 2 - 4 } & Hizki homofonoak & brb (be right back) & zmz (zer moduz zaude) \\
\cline { 2 - 4 } & «h»rik gabe & & wapa (guapa) \\
\hline \multirow{3}{*}{$\begin{array}{l}\text { pragmatiko } \\
\text { eta } \\
\text { emozionalak }\end{array}$} & Hizkiak luzatzea & Hellooo & Kaixooo (kaixo) \\
\cline { 2 - 4 } & Hizki larriak & WHAT (What) & ZER ( Zer) \\
\cline { 2 - 4 } & Emoziozko hitzak & Hahahah & Jajajajaj \\
\cline { 2 - 4 } & Emoziozko puntuazioa & !!!! & !!!! \\
\hline \multirow{3}{*}{ 3. Akatsak } & Tipografikoak & Carzy (crazy) & iksui (ikusi) \\
\cline { 2 - 4 } & Ortografikoak & progect (project) & azpaldi (aspaldi) \\
\hline
\end{tabular}


2. taulan ageri diren emaitzek erakusten dute ingeleserako erabilitako taxonomiak euskararentzako ere baliagarriak direla. Ordenagailu bidezko komunikazioan erabiltzen den hizkuntzaren ezaugarriak hiru kategoria nagusitan sailkatu daitezke: laburdurak, baliabide pragmatikoak eta akatsak.

1. Laburdurak. Kategoria honen barruan sailkatu ditugu guk jaso dugun euskarako corpusean ikusi ditugun hainbat ezaugarri linguistiko. Ikusi dugu ezaugarri linguistiko horiek antzekoak direla ingelesez eta euskaraz:

- Hitzen konbinazioa. Bi hitz edo gehiagoren arteko konbinazioa askotan egiten dela ikusi dugu euskaraz, esaterako: eztakit, «ez dakit» idatzi beharrean; junber, «joan behar» idatzi beharrean. Hitzak konbinatzea oso ohikoa da euskalkietan aritzean, eta guk jasotako corpusaren \% 100 euskalkian idatzita zegoenez, ezaugarri hau maiztasun handiz agertzen da. Hala ere, ez dakigu ezaugarri hau ordenagailu bidez komunikatzeko erabiltzen den hizkuntzaren ezaugarritzat hartu behar dugun ala euskalkia erabiltzearen ondorio moduan ikusi behar dugun.

- Laburdurak. Hitzen barruko zenbait hizki jan egiten dira, esaterako: on, «ondo» idatzi beharrean; bstla «bestela» idatzi beharrean. Eta hori horrelaxe gertatzen da ingelesez ere.

- Akronimoak. Ezaugarri hau ere modu berean erabiltzen da bai ingelesez eta bai euskaraz; esaterako: $z m z$, «zer moduz zaude» idazteko.

- Hizki-aldatze homofonoak. Asko izan ez arren, zenbait kasutan aurkitu ditugu hizki-aldatze homofonoak; esaterako: wapa, «guapa» idatzi beharrean.

- «h»rik ez erabiltzea. Ezaugarri hau nabarmendu dute ingelesaren gainean egindako beste ikerketa batzuek ere (Tagg, 2012); honelako kasuetan, esaterako: wat, «what» idatzi beharrean. Gure kasuan ezaugarri hau bereziki nabarmendu nahi izan dugu bere izaera bereziarengatik eta gure datuetan maiztasun handiz agertu delako. Ingelesa ez bezala, euskara hizkuntza gardena da, alegia, fonema-ortografia korrespondentzia dago. Ipar Euskal Herriko zenbait tokitan «h»a ahoskatu egiten den arren, hego Euskal Herrian hizki mutua da eta agian hori izan liteke ezaugarri hau horrenbesteko maiztasunez agertu izanaren arrazoietako bat (hala ere, horretarako beste arrazoi batzuk ere egon litezke, hala nola: nahigabeko akatsak izatea edo hizkuntza estandarraren arauak hausteko borondatez egindako ekintza bat izatea).

2. Baliabide pragmatiko eta emozionalak. Kasu honetan ere gure corpusean aurkitutako baliabideak ingelesaren kasuan aurkitu izan direnen antzekoak izan dira. 
- Hizkiak luzatzea. Ikusi dugu baliabide hau modu berberean erabiltzen dela bai ingelesez eta bai euskaraz; esaterako: kaixoooo, «kaixo» esateko.

- Hizki larriak. Baliabide hau ere bi hizkuntzetan erabiltzen da hizkuntzaren ahozko aldaeran bolumen altuagoz hitz egiten den kasuak irudikatzeko, esaterako: EZ ETS!!!, «ez etsi»-ren tokian.

- Emoziozko hitzak. Baliabide hau ere modu bertsuan erabiltzen da bai ingelesez eta bai euskaraz; adibidez: Jajajajaj.

- Emoziozko puntuazioa. Bi hizkuntzetan erabiltzen da baliabide hau ere, esaterako: !!!!!.

3. Akatsak. Ezaugarri hau ere bi hizkuntzetan ageri da, baina badira zenbait desberdintasun:

- Akats tipografikoak. Mota honetako akatsak bi hizkuntzetan gertatzen dira, eta ordenagailuaren teklatua erabiltzeko trebetasunarekin eta idatzitakoa editatu gabe bidaltzearekin lotuta daude. Adibidez: $i k s u i$, «ikusi» idatzi beharrean; huandi, «haundi» idatzi beharrean.

- Akats ortografikoak. Lehenago azaldu dugun moduan, akats mota hau urriagoa da euskaraz, fonema-ortografia korrespondentzia daukan hizkuntza bat delako. Euskaraz egin daitezkeen akats ortografikoak ez dira asko; esaterako: «s» eta «Z» hizkiak nahastea; hotzein idaztea «hotsein»en ordez. Eta «h»rik ez jartzea ere izan liteke akats ortografiko bat, baina kasu honetan ezaugarri hori laburdura moduan sailkatu dugu.

Ordenagailu bidez komunikatzeko erabiltzen den hizkuntzak dituen ezaugarriak aztertzeaz gain, garrantzitsua da ezaugarri horiek zer maiztasunekin erabiltzen diren aztertzea. Beheragoko 3. taulan ikus daiteke corpusean identifikatutako ezaugarri bakoitzaren maiztasuna.

Ikus dezakegunez, ezaugarri guztiak kontuan hartuta maiztasun altuenaz errepikatzen den ezaugarria laburduren multzoan sailkatu dugun «h» hizkia ez erabiltzea da $(\%$ 64,1). Hizkiak ekonomizatzeko estrategia bat hizkuntza ahoskatzen den moduan idaztea da, arau ortografikoak errespetatuz idatzi beharrean. Ahozko hizkuntzara gerturatzeko erabiltzen diren estrategien artean erabiliena emoziozko puntuazioa da $(\% 26,8)$, eta ia maiztasun berdinez errepikatzen da hizkiak luzatzea (\% 25,9). Hizkiak konbinatzea ere nahiko ohikoa dela ikusten dugu $(\%$ 11,3). Beste zenbait testismo maiztasun gutxiagorekin agertzen direla ikusi dugu; esaterako: laburdurak $(\% 5,0)$ eta emozio-hizkiak $(\% 5,3)$.

Bigarren ikerketa-galderarekin ikerketan parte hartutako gazteek berek ordenagailu bidezko komunikazioan erabiltzen duten hizkuntzari buruz daukaten pertzepzioa aztertu dugu. Zehatzago esanda, jakin nahi izan dugu zein diren gazte horien ustez ordenagailu bidez komunikatzerakoan testismoak erabiltzeko arrazoiak. Berek esandakoaren arabera honako kategoria 
Testuinguru euskalduneko gazteek OBKan erabiltzen duten hizkuntzaren ezaugarrien ehunekoak

\begin{tabular}{l|lc}
\hline \multicolumn{1}{c|}{ Ezaugarriak } & & Ehunekoak \\
\hline & Hitzen konbinazioa & 11,3 \\
& Laburdurak & 5,0 \\
1. Laburdurak & Akronimoak & 0,7 \\
& Hizki homofonoak & 0,2 \\
& «h»rik gabe & 64,1 \\
\hline \multirow{3}{*}{ 2. Baliabide pragmatiko eta emozionalak } & Hizkiak luzatzea & 25,9 \\
& Hizki larriak & 0,5 \\
& Emoziozko hitzak & 5,3 \\
& Emoziozko puntuazioa & 26,8 \\
\hline \multirow{2}{*}{ 3. Akatsak } & Tipografikoak & 1,5 \\
& Ortografikoak & 0,3 \\
\hline
\end{tabular}

hauek identifikatu ditugu: ordenagailu bidez komunikatzen direnean ikastetxean erabiltzen duten hizkuntza-aldaeratik desberdina den aldaera bat erabiltzeko nahia, laburdurak erabiltzeko beharra, ohitura bihurtu izana, denboran zehar aldaketak egon izan direla, hizkuntzaren ahozko aldaeratik gertu dagoen aldaera erabiltzeko joera, taldekide-sentipena eta sexuen artean dauden desberdintasunak. Hona hemen bakoitzari buruz jasotakoak:

1. OBKn erabiltzen duten hizkuntza versus ikastetxeko hizkuntza. Ikasle hauek D ereduan ikasten dute, hau da, ikasgai gehienak euskaraz lantzen dituzte. Eta ikastetxean erabiltzen duten euskara hizkuntzaren aldaera estandarizatua da; alegia, euskara batua. Ikasle horiek berehalako mezularitzan euskalkia erabiltzen dute eta horretarako arrazoiak zein diren galdetuta, batetik, esaten dute ez dutela euskara batua erabili nahi, ez dutela ikastetxean erabiltzen den hizkuntza-aldaera erabili nahi. Ikusi 1. pasartea:

1. pasartea

Ikertzailea: Pixket honei buruz geyo zeoze esatie ba al dakezute? Ze nik garbi ikusi detena da euskalkiye ibiltzezutela erabat.

1. ikaslea: bai, formala egiye da igual eskoliekin lotze deula. Eta ordun nola eskolan ite deun ezteu nahi ezer jakitie ya horrekin.

Eta, bestetik, esaten dute euskalkia erabiltzen dutela ahalik eta modurik naturalenean komunikatzeko. Ikusi 2. pasartea: 


\section{2. pasartea}

2. ikaslea: nik ustet igual naturalakin lotze deula euskalkiye, porke batuaz hitzeiten hasiko bagiñeke tuentitiken, nik ustet faltsuo gerauko zala

3. ikaslea: Eskaso...

4. ikaslea: zuk gañea, idaztezun bezela notau itezu beak nola... ezautzebaezu, zea ai dan pentsatzen igual-eo...

Ikertzailea: Ze esan nahi dun?

4. ikaslea: klaro. Hori igual, eztakit... ze helburu dakeneooo... nola ezautu ite zean, hitzeiteko eran-da hori pixket interpretau in leizkezu

2. Laburdurak erabiltzeko beharra. Ikasleek laburdurak erabiltzeko beharra sentitzen dute ordenagailu edo telefono mugikor bidez komunikatzen direnean. Iruditzen zaie gailu teknologikoak erabiltzearekin bat datorren zerbait dela hori. Bosgarren ikasleak dioen moduan, izan liteke laburdurak erabiltzeak gailu teknologikoen bidez komunikatzea erraztu egiten duela. Seigarren eta zazpigarren ikasleek ere ideia hori berresten dute eta esaten dute ordenagailu bidez komunikatzeko erabiltzen den hizkuntza desberdina dela.

\section{3. pasartea}

5. ikaslea: eske ordenadoran idazteakun edo mobilin mensaje bat

bialtzezunin, ahal dezun motxena.

Ikertzailea: bokala kendu...

6. ikaslea: bai, edo beste era batea idaztezu

7. ikaslea: edo «h» gabe. Igual zuk, normalin zuk «h»ik eztezu idazten ordenadorin-da hola

3. Ohitura bihurtu izana. Hirugarren pasartean dagoenekoz ikusi dugu zenbait testismo mota ohitura bihur litezkeela. Hala eta guztiz ere, hori oraindik eta nabarmenago gelditzen da zortzigarren eta bederatzigarren ikasleek laugarren pasartean bokalak luzatzeari buruz diotena ikusita. Ohitu egin dira horrela idaztera eta horrela egiten dute, nahiz eta ez dakiten ohitura horretaz noiz jabetu ziren.

4. pasartea

Ikertzailea: eta zeatiken itezute hori?

8. ikaslea: ya ohitu in naiz, ni behintzet. Hasiko nitzen eunen baten da ya...

9. ikaslea: eske ya jun itea bi aldiz zapaltzie teklie...jaja 
Gainera, ikasle batzuek esan dutenez, aspertuta daudenean joera gehiago izan ohi dute modu horretan idazteko:

5. pasartea

Ikertzailea: bokalak luzatze kontu hori pixket ahozkoa gerturatzeko dala

Ikasleak: bai

10. ikaslea: geyenbat aspertute zaudenin, hola

11. ikaslea: Hori egiya da...

10. ikaslea: Batzutan, aspertuta zaudenin geyo luzatzeituzu

6. Denboran zehar egon diren aldaketak. Aurkikuntza interesgarri bat izan da ikustea sare sozial birtualak erabiltzen hasiberriak zirenean zenbait ezaugarri gehiago erabiltzen zituztela eta denborarekin ohiturak aldatzen joan direla. Esaterako, hasieran $z m z$ (zer moduz zaude) gisako akronimoak erabiltzeko joera handia zeukatela esan digute, baina gerora elkarrizketei hasiera edo amaiera emateko formula gisa besterik ez dituztela erabiltzen. Dirudienez laburduren erabilpena bere garapena izaten ari da, 6. eta 7. pasarteetan ikus dezakegun moduan:

6. pasartea

12. ikaslea: [...] txikitan... [...] messengerrakin haste zeanin da, igual, «zmz» igual «zemouz» galdetzeko, baño oin ya ez, nik behintzat ez

13. ikaslea: $e z$

Ikertzailea: ya haundiyek zeate ta

14. ikaslea: eske hori hasierako emoziyue da. Hasieran bat hastea ta, hola idazteik ordenadoran... baño gero ya pasau itezu.

\section{7. pasartea}

15. ikaslea: Ez, baño... oaiñ pixkat haundiyak bezela gea... Oaiñ bukaeran, ohitura bezela «aio $m x »$

7. Hizkuntzaren ahozko aldaerara gerturatzeko nahia. Ikasleak ohartzen dira OBKn hizkuntza-aldaera berezi bat erabiltzen dela eta ahozko hizkuntzaren ezaugarriak dituela, hots, ahozkotik gertu dagoen aldaera dela. Zortzigarren pasartean irakur dezakegun 18. ikaslearen adierazpenaren arabera, behintzat, OBKn erabiltzen den hizkuntzak ahozkoa imitatu nahi du eta hori da hitzak laburtu 
zein luzatzearen arrazoia. Dirudienez baliabide pragmatiko eta emozionalak erabiltzeko beharra sentitzen da nolabait ahozko hizkuntzaren intonazioa eta keinuak konpentsatzeko, 8. eta 9. pasarteetan ikus dezakegunez:

\section{8. pasartea}

16. ikaslea: eta letrak luzau're...

Ikertzailea: eta letrak luzau, hori bestie

17. ikaslea: eske «epa» bat hola bakarrik oso bordie sonau leike

18. ikaslea: nola hitzeite deun bezela nahi deun idatzi, ba atea ite zaizu luzio eo motzo

9. pasartea

19. ikaslea: zea sonatzeu... [bokalak luzatuta]

20. ikaslea: irikiyo bezela...

19. ikaslea: Baai! Igual «epaaaaaa» jarrita ba...

Ikertzailea: «iepa» esanberrin «iepaaaa» edo «aiooooo» edo?

19. ikaslea: Bai, porke «aio» oso...pun!

21. ikaslea: Emanber kabreaute zaudela

8. Taldekide-sentipena. Zortzigarren pasartean 17. ikasleak esandakoaren arabera, badirudi taldeko kide izatea garrantzitsua dela. Elkarrizketa bateko agur moduan «epa» soil bat idaztea zakar xamarra iruditzen zaie nonbait, eta, beraz, beharrezko ikusten dute bokalak luzatzea (intonazioa goxatuz) taldeko gainontzeko kideen onarpena jasotzeko. Hamargarren pasartean ere ikusten da taldeko beste kideek izan ditzaketen erreakzioak kontuan hartzen dituztela eta, esaterako, horren adibide da elkarrizketen amaieran emoziozko hitzak erabiltzeko joera. Hala, 22. ikaslearen arabera elkarrizketa bat «mихи bat» ekin amaitzea elkarrizketa hori izaten ari diren kideen artean dagoen gertutasuna erakusteko zeinu bat da. Interpretazio hori berresten du 23. ikasleak ere, berak «mxl» laburdura erabiltzen du «mихи bat»en tokian.

9. pasartea

22. ikaslea: «muxu bat» hori tipikue da, hori konfiantzie bezela $d a$

23. ikaslea: bai. «mxl»

11. pasartean oraindik eta argiago dihardute lagun-talde bateko

kide gisa onartzeko bete behar diren arauez: 
10. pasartea

24. ikaslea: Neskak errexo idaztebe hori [afektuzko akronimoak]

25. ikaslea: Ohitura bat bezela hartzebe ya. Edozer komentayo ta bukaeran hori jarriber.

Ikertzailea: Bukaeran muxuek eta «maite zaitut» bialduber? Eta ezpazu idazten?

25. ikaslea Askokigual geixki hartu

26. ikaslea Igual ya ez nau matte [ironiaz]

11. Sexuen artean dauden desberdintasunak. Elkarrizketa baten amaierako agurrean muxuak bidaltzea ohitura bilakatu da baina desberdintasunak daude nesken eta mutilen artean. Ikasleek esan dutenez, neskek beti egiten dute hori baina mutilek ez dute horrelakorik egiten beste mutil batzuekin dihardutenean.

\section{2. pasartea}

27. ikaslea: ... bukaeran ohitura bezela «aio $m x »$

Ikertzailea: ohitura bezela, ez?

27. ikaslea: bai. Lagunai're bai «mxx» edo «mx»

Ikertzailea: eta zuek, mutilek'e bai hori? holako afektu erakuste holako zeaik?

28. ikaslea: mutilen artin ez.

Horrez gain, ordenagailu bidez komunikatzen direnean neskek eta mutilek komunikatzeko estilo desberdinak dauzkatela azaltzen dute 13. pasartean:

\section{3. pasartea}

29. ikaslea: gero baita, mutil batekin hitzein edo neska batekin hitzein diferentie da.

Ikertzailea: bai?

29. ikaslea: nere ustez bai, behintzet

Ikertzailea: Zeatik? Zertan?

29. ikaslea: Eztakit, diferente hitzeitezu

Ikertzailea: Idatziyen edo ahoz?

29. ikaslea: Idatziyen

Ikertzailea: Tuentiyen?

29. ikaslea: Bai. Igual, mutil batekin motzo

Ikertzailea: «gero ze ordutan?» eta hola? 


\author{
30. ikaslea: [...] igual neskak gauz bat galdetzeko «epaaa» \\ ta «epaaa» eta «zemouz» eta dana galdetzebe \\ eta gero ordun «ze ordutan geldiuko gea?» \\ Ikasle neskak:Jajajaja \\ 30 Ikaslea: Eta gu, ba, direkto, «ze ordutan?»
}

\title{
ONDORIOAK / EZTABAIDA
}

Esku artean dugun ikerketak ordenagailu bidez komunikatzeko erabiltzen den hizkuntza du ikergai; zehazki, berehalako mezularitzako euskara. Batetik, euskararen kasuan hizkuntza horrek dituen ezaugarriak aztertu dira. Eta, bestetik, parte-hartzaileek testismoak erabiltzearen inguruan dauzkaten pertzepzioak ikertu dira.

Ordenagailu bidez komunikatzeko erabiltzen den hizkuntza-aldaera horrek dituen ezaugarriak aztertu eta ingelesaren eta euskararen arteko konparaketa egin dugu. Ikusi nahi izan dugu ea, berez hizkuntza gutxitua izan arren, komunikatzeko hizkuntza nagusia euskara den eta ingelesaren esposizioa oso mugatua den testuinguru batean zenbaterainoko antzekotasunak dauden euskararen eta ingelesaren artean. Modu horretan ordenagailu bidez komunikatzeko erabiltzen den hizkuntzaren ezaugarriak unibertsalak izan ote daitezkeen aztertu dugu. Eta jasotako datuek norabide horretan jartzen gaituzte.

Ikerketa honetako corpusaren azterketak erakusten du euskararen eta ingelesaren artean badaudela antzekotasunak (De Jonge eta Kemp 2012; Grace et al., 2014; Ling eta Baron 2007; Varnhagen et al. 2010). Izan ere, Varnhagen eta beraren kideek (2010) egindako taxonomian proposatzen diren kategoriak eta azpi-kategoriak erabilgarriak dira euskararen kasuan ere. Taxonomia horretan sailkatzen diren ezaugarri nabarmenenak euskararen kasuan ere aurkitu ditugu. Antzekotasun horiek hainbat faktoreri lotuta egon daitezke. Eta puntu honetan interesgarria da ordenagailu bidez komunikatzeko erabiltzen den hizkuntzaren ezaugarriak aztertzearekin batera erabiltzaileek horren inguruan jakinarazi dizkiguten pertzepzioak uztartzen joatea.

Berehalako mezularitzak erreakzio azkarrak eskatzen ditu eta teklatua erabili beharrak zenbait muga ezartzen ditu; beraz, ez da harritzekoa, ordenagailu bidez komunikatzeko hizkuntza edozein izanda ere, laburdurak erabiltzea. Mezuak laburtzeko dauden aukerak mugatuak dira eta antzeko estrategiak erabiltzen dira bai ingelesez eta bai euskaraz; hori ez da arraroa. Talde-eztabaidetan jasotako datuek ere erakusten dute parte-hartzaileek beharrezkotzat jotzen dutela mezuak laburrak izatea. Orokorrean testismoak erabiltzearen atzean dauden motibazioak aztertzeko egin izan 
diren zenbait ikerketak (Drouin eta Drive 2014, Grace et al. 2014) erakutsi dute testismoak erabiltzeko arrazoiak lotuta egon daitezkeela sormenez idazteko gogoarekin, utzikeriarekin edo zuzentasunez idazteko ezintasunarekin; eta guk egindako talde-eztabaidetan ikusi dugunez, bada beste arrazoi bat ere: testismoak erabiltzea ohitura bihurtu izana, hain zuzen ere. Ikerketek mahai gainean jarri dituzten arrazoiak alde batera utzi gabe, guk ikusi dugu agian erabiltzaileek ez dutela zergatiaren kontzientziarik eta ohituraz edo inertziaz erabiltzen dituztela testismoak, eta hori ere kontuan hartzeko arrazoi bat iruditzen zaigu. Horrekin batera, paragrafo honen hasieran aipatu ditugun faktoreak (denboraren presioa eta gailuen ezaugarri teknikoak) izan daitezke zenbait ortografia akatsen arrazoi ere.

Baliabide pragmatiko eta emozionalak erabiltzeko orduan aurkitu ditugun antzekotasunen zergatia azaltzea zailagoa da. Ikerketa honetako partehartzaileek esaten dutenez, hizkiak luzatzea ahozko hizkuntzara gerturatzeko egiten dute eta emoziozko hitzak taldeko kideen arteko gertutasuna adierazteko erabiltzen dira. Baliabide horiek beste zenbait ikerketatan ere agertu izan dira (Varnhagen et al. 2010; De Jonge eta Kemp 2012; Grace et al. 2014). Baina euskal hiztunek zergatik erabiltzen dituzte ingeles hiztunek erabiltzen dituzten baliabide berberak (hizki larriak, hizkiak errepikatzea, emoziozko puntuazioa)? Zergatik garatu dituzte baliabide zehatz hauek eta ez beste batzuk? Horretarako arrazoi bat izan liteke modu batean edo bestean ingelesetik jasotzen duten eragina. Gure ikerketako parte-hartzaileek ez dute ingelesik erabiltzen bere eguneroko bizitzan, baina ezin dugu saihestu, zeharkako moduan bada ere, ingelesarekin izan dezaketen kontaktua. Litekeena da filmen batean ingelesezko testismoak ikustea, nahiz eta filma euskarara edo gaztelaniara bikoiztuta egon. Baliteke, agian, ikerketa honetako parte-hartzaileek ingelesarekin harreman gehiago daukaten lagunekin harremana izatea.

Aukera horiek ezin dira saihestu, baina, hala ere, interesgarria da, esaterako, akronimoen erabileran dauden joerak antzekoak izatea hizkuntza nahiz testuinguru desberdinetan. Tagliamonte eta Denis-ek Kanadako nerabeekin egindako ikerketa batean (2008:13) esaten da «the use of $l o l$ declines systematically according to age, with the younger individuals using it the most «. Era berean, nerabe euskaldunekin egindako talde-eztabaida batean esaten da $z m z$ akronimoa berehalako mezularitzan komunikatzen hasi berritan erabiltzen zutela. Bai batean eta bai bestean, nerabeek zenbait ezaugarriren erabilera garatu egin dutela ikusten da. Interesgarria da ikustea bi kasuetan asko erabili izan dituzten akronimoekin gertatu dela hori. Komunikatzeko bide berriek komunikatzeko modu berriak ekarri dituzte eta ikusten da erabiltzaileak horretarako hizkuntza eta ohiturak egokitzen eta garatzen ari direla. Esan ote dezakegu hizkuntza aldaera hori egonkortzen ari dela? Tagliamonte eta Denis-ek (2008:27) esaten duten moduan: «perhaps computer-mediated communication [...] 
is not the ruin of this generation at all, but an expansive new linguistic renaissance», eta, beraz, ikusteko dago aurrerantzean horrek zer bilakaera izango duen.

Bi hizkuntzen artean dauden antzekotasunei begira jarrita, ikusten dugu antzekotasun horiek lotuta daudela nerabeek beren identitate soziala garatzeko daukaten beharrarekin, beren gurasoengandik edo beren ikastetxekoengandik (alegia, berek autoritate gisara ikusten dituzten horiengandik) bereizi nahi izatearekin, eta horrek bat egiten du beste ikerketa batzuek diotenarekin (Ling eta Ytri 2002, Amonarriz 2008). Tagg -ek (2012:19) esaten duen moduan: «Respellings in texting can carry social meaning: they create a sense of spoken informality and intimacy, they signal deviance from the norm and they create an illusion at least of brevity». Nerabezaroan identitate soziala garatzeko prozesuak hainbat ezaugarri elkarbanatu ditzake jendarte, herrialde edo kultura desberdine$\tan$. Ezaugarri horietako bat genero identitatearena izan liteke eta interesgarria da ikustea talde-eztabaidetako batean emakumezko parte-hartzaileek esaten dutela gizonezkoek baino emoziozko hitz gehiago erabiltzen dituztela. Neska eta mutilen arteko desberdintasunak beste ikerketa batzuetan ere agertu izan dira (Kapidzik eta Herring 2011; Herring eta Kapidzic 2015).

Eta identitate soziala garatzearekin batera taldekide-sentipena indartu nahi dutela ere ikusi dugu. Ikerketa gehiagok ere aipatu dute ordenagailu bidez komunikatzeko erabiltzen den hizkuntzan testismoak erabiltzeko joera lotuta dagoela taldekide-sentipena bermatzearekin (Ling eta Ytri 2002; Baron 2003; Kemp, Wood eta Waldon 2014) eta gure datuek ere gauza bera erakutsi digute. Ikerketako parte-hartzaileekin talde-eztabaidak egin eta testismoak erabiltzearen inguruko pertzepzioei buruz aritu garenean behin baino gehiagotan aipatu duten gaia izan da. Batetik, hizkuntzaren ahozko aldaerara gerturatzeko estrategiak (hizkiak luzatzea edota emoziozko puntuazioa) erabiltzen dituzte, eman nahi duten mezua modalizatzeko eta hartzaileak egin behar duen interpretazioa argitzeko. Eta, bestetik, elkarrizketen amaieran emoziozko hitzak erabiltzea edo elkarrizketa muxu bat bidaliz amaitzea esan gabekoak diren baina hor dauden arau sozial modura ulertzen dituzte.

Hala eta guztiz ere, badira euskarazko corpusean identifikatu ditugun zenbait elementu, ingelesetik desberdintzen direnak. Desberdintasun horiek ezaugarri linguistikoen maiztasunarekin lotuta daude, ez horrenbeste ezaugarri motekin. Eta horren arrazoiak euskararen ezaugarrietan eta euskalkiaren erabileran aurki genitzake. Esaterako, hitzak konbinatzea maiztasun goreneko ezaugarrien artean dago euskararen kasuan; ezaugarri hori ez da hainbesteko maiztasunez agertzen beste ikerketa batzuetan (Varnhagen et al. 2010, Drouin eta Drive 2014). Azaldu dugun bezala, horren arrazoia da gure ikerketako parte-hartzaileek ahoz erabiltzen duten euskalkia erabiltzen dutela ordenagailu bidez idatziz komunikatzeko ere, eta euskalkia era- 
biltzean hitzen konbinazioak maiztasun handiz egiten dira. Hizkuntzaren idatzizko aldaeran dialektoak erabiltzearen inguruan idatzi izan da beste ikerketa batzuetan ere (Tagg 2012).

Euskaraz oso adibide gutxi daude ortografia akatsenak eta hizki-aldaketa homofonoenak, «h» hizkiaren kasuan izan ezik. Euskara hizkuntza gardena da, fonema-ortografia korrespondentzia daukana eta horrek azal lezake euskaraz zergatik dauden desberdintasun gutxiago ingelesez baino, ordenagailu bidez komunikatzeko erabiltzen den hizkuntzaren eta hizkuntzaren aldaera estandarraren artean.

Laburbilduz, ikerketa honek erakusten du ordenagailu bidez komunikatzeko hizkuntzari dagokionez eta, gehiago zehaztuz, berehalako mezularitzan erabiltzen den hizkuntzari dagokionez euskararen eta ingelesaren artean dauden antzekotasunak gehiago direla desberdintasunak baino. Elkarrizketa errealetatik jasotako euskarazko corpus naturalistikoa aztertu izanak eta talde-eztabaidetan nerabeek berek testismoak erabiltzearen gainean daukaten ikuspuntua aztertu izanak esanguratsu bihurtzen dute ikerketa hau. Ikerketa honen bidez mahai gainean jarri dugu testismoen unibertsaltasuna ingelesaren presentzia oso ahula den testuinguru batean. Horrekin batera, ikerketarekin ikusi dugu testismoak erabiltzearen atzean dauden arrazoiak ez direla berehalako mezularitzaren ezaugarri teknologikoekin lotuta dauden horiek bakarrik, baizik eta arrazoi horiek bezainbesteko pisua daukatela hizkuntza bakoitzaren ezaugarriek eta identitate sozialak eratzeko prozesuek edo talde bateko kide izateko bete beharreko arauek (ikusi Grace et al. 2014). Faktore horien konbinazioak azal ditzake nerabeen artean berehalako mezularitzan erabiltzen diren hizkuntzen ezaugarrien arteko antzekotasunak eta desberdintasunak.

\begin{abstract}
The development of technology has brought along new methods of communication that directly affect the use of languages. In this article we analyse issues related to how multilingual adolescents from a Basque sociolinguistic context use languages when using one of the new methods of communication that is instant messaging. On the one hand, we analyse the characteristics of the language used when writing in an informal context. And on the other hand, we analyse qualitatively the perception the users have on those characteristics. By placing the
\end{abstract}


focus on Basque, this article aims at contributing to enhance the research done internationally in this field.

Keywords: Computer Mediated Communication (CMC), textisms, Insta Messaging (IM), Basque language.

Con el desarrollo de la tecnología han emergido nuevas vías y nuevas maneras de comunicación y eso influye directamente en el uso del lenguaje. Entre las nuevas vías de comunicación que han surgido se encuentra la mensajería instantánea. En este artículo se analizan cuestiones relacionadas con el uso del lenguaje que hacen los adolescentes multilingües de un contexto sociolingüístico vascohablante en la comunicación por medio de mensajería instantánea.

Por una parte, se analizan las características del lenguaje escrito utilizado en un contexto informal. Y por otra parte, se hace un análisis cualitativo de las percepciones que tienen los usuarios con respecto a ello. Al poner el foco en el euskara, el presente artículo intenta hacer una aportación que enriquezca la investigación que se está llevando a cabo sobre este tema a nivel internacional.

Palabras clave: Comunicación por medio de computadoras $(C M C)$, testismos, mensajería instantánea, euskara (lengua vasca).

Le développement de la technologie a fait émerger de nouvelles façons de communication qui ont une influence directe sur l'usage de la langue. Dans cet article, nous abordons la question de l'usage de la langue que font les adolescents multilingues d'un contexte sociolinguistique bascophone lorsqu'ils se communiquent par messagerie instantanée. D'une part, nous analysons les caractéristiques du langage écrit employé en contexte informel. D'autre part, nous faisons une analyse qualitative des perceptions des usagers à l'égard de ce langage. En mettant l'accent sur l'euskara, cet article voudrait contribuer à enrichir les recherches en cours sur ce sujet au niveau international.

Mots-clé: Communication Médiée par Ordinateur (CMO), textismes, Messagerie Instantanée, euskara (langue basque). 


\section{ERREFERENTZIAK}

Amonarriz, K. (2008). Gazte hizkerak - hizkera gazteak. BAT Soziolinguistika Aldizkaria, 68,167-183.

Androutsopoulos, J. K. (2000). Non-standard spellings in media texts: The case of German fanzines. Journal of Sociolinguistics, 4, 514-533.

Androutsopoulos, J. (2015). Networked multilingualism: Some language practices on Facebook and their implications. International Journal of Bilingualism, 19(2) 185-205. doi: 10.1177/1367006913489198

Baker, R. K. eta White, K. M. (2010). Predicting adolescents' use of social networking sites from an extended theory of planned behaviour perspective. Computers in Human Behavior, 26, 1591-1597.

Baron, N. S. (2003). Language of the internet. In A. Farghali (Ed.), The Stanford handbook for language engineers (pp. 59-127). Stanford: CSLI Publications.

Baron, N. S. (2004). See you online: Gender issues in college student use of instant messaging. Journal of Language and Social Psychology, 23, 397-423.

Crystal, D. (2001). Language and the internet. Cambridge: Cambridge University Press.

Danet, B., eta Herring, S. C. (2007). Multilingualism on the Internet. In M. Hellinger eta A. Pauwels (Eds.), Language and Communication: Diversity and Change. Handbook of Applied Linguistics 9 (pp. 553-592). Berlin: Mouton de Gruyter. http://ella.slis.indiana.edu/ herring/danet.herring.hb.pdf

De Jonge, S. eta Kemp, N. (2012). Text-message abbreviations and language skills in high school and university students. Journal of Research in Reading, 35, 49-68. doi:10.1111/j.1467-9817.2010.01466.x.

Drouin, M. eta Driver, B. (2014). Texting, textese and literacy abilities: a naturalistic study. Journal of Research in Reading , 37, 250-267. Doi: 10.1111/j.14679817.2012.01532.x

Dyers, C eta Davids, G. (2015). Southern African Linguistics and Applied Language Studies Post-modern 'languagers': the effects of texting by university students on three South African languages. Southern African Linguistics and Applied Language Studies 33(1):21-30. doi: 10.2989/16073614.2014.999994

Grace, A., Kemp, N., Martin, F. H., eta Parrila, R. (2014). Undergraduates' text messaging language and literacy skills. Reading and Writing, 27, 855-873. doi: $10.1007 / \mathrm{s} 11145-013-9471-2$

Grace, A., Kemp, N., Martin, F. H., eta Parrila, R. (2015). Undergraduates' attitudes to text messaging language use and intrusions of textisms into formal writing. New Media eta Society, 17(5), 792-809. doi: $10.1177 / 1461444813516832$

Herring, S. C. (1996). Introduction. In S. C. Herring (Ed.), Computer-Mediated Communication: Linguistic, Social and Cross-Cultural Perspectives (pp. 1-10). Amsterdam: Benjamins.

Herring, S. C. (2010). Computer-mediated conversation: Introduction and overview.Language@internet, 7.http://www.languageatinternet.org/articles/2011/ Herring Eskuratze-data 2015eko maiatzak 21.

Herring, S. C., Stein, D., eta Virtanen, T., (2013). Introduction to the pragmatics of computer-mediated communication. In Herring, S. C., Stein, D., eta Virta- 
nen, T. (Eds.), Handbook of pragmatics of computer-mediated communication (pp. 3-31). Berlin: Mouton.

Herring, S.C. eta Kapidzic, S. (2015). Teens, Gender, and Self-Presentation in Social Media. In J.D. Wright (Ed.), International Encyclopedia of Social and Behavioral Sciences (2nd edition) (pp. 146-152). Oxford: Elsevier.

International Telecommunication Union (2015). ICT. Facts eta Figures. The world in 2015. http://www.itu.int/en/ITU-D/Statistics/Documents/facts/ICTFactsFigures2015.pdf. Eskuratze-data 2016ko ekainak 6.

Kapidzic, S. eta Herring, S.C. (2011). Gender, communication, and self-presentation in teen chatrooms revisited: Have patterns changed?. Journal of Computer-Mediated Communication, 17, 39-59.

Kemp, N., Wood, C. eta Waldron, S. (2014). do i know its wrong: children's and adults' use of unconventional grammar in text messaging. Reading and Writing, 27, 1585-1602. doi: 10.1007/s11145-014-9508-1

Lenhart, A., Purcell, K., Smith, A. eta Zickuhr, K., (2010). Social media and mobile Internet use among teens and young adults. Pew Internet and American Life Project. http://pewinternet.org/ /media//Files/Reports/2010/PIP_Social_ Media_and_Young_Adults_Report_Final_with_toplines.pdf . Eskuratzea-data 2012ko martxoak 17.

Ling, R. eta Yttri, B. (2002). Hyper-coordination via mobile phones in Norway. In J. E. Katz eta M. Aakhus (Eds.), Perpetual contact: Mobile communication, private talk, public performance (pp. 139-169). Cambridge, UK: Cambridge University Press.

Ling, R. eta Baron, N. (2007). Text messaging and IM: Linguistic comparison of American college data. Journal of Language and Social Psychology, 26, 291298. doi:10.1177/0261927X06303480

Plester, B., Wood, C. eta Joshi, P. (2009). Exploring the relationship between children's knowledge of text message abbreviations and school literacy outcomes. British Journal of Developmental Psychology, 27, 145-161. doi: $10.1348 / 026151008 \times 320507$

Tagg, C. (2012). Discourse of Text Messaging. London : Continuum.

Tagliamonte, S. A. eta Denis, D. (2008). Linguistic ruin? LOL! instant messaging and teen language. American Speech, 83, 3-34.

Thurlow, C. (2006). From statistical panic to moral panic: The metadiscursive construction and popular exaggeration of new media language in the print media. Journal of Computer-Mediated Communication, 11, 667-701.

Thurlow, C., Lengel, L. eta Tomic, A. (2004). Computer mediated communication: Social interaction and the internet. London: Sage.

Varnhagen, C. K., MacFall, G. P., Pugh, N., Routledge, L., Sumida-MacDonald, H. eta Kwong, T. E. (2010). Lol: New language and spelling in instant messaging. Reading and Writing, 23, 719-733. 